\title{
Facial transplantation: the first 9 years
}

Saami Khalifian, Philip S Brazio, Raja Mohan, Cynthia Shaffer, Gerald Brandacher, Rolf N Barth, Eduardo D Rodriguez

Since the first facial transplantation in 2005, 28 have been done worldwide with encouraging immunological, functional, psychological, and aesthetic outcomes. Unlike solid organ transplantation, which is potentially life-saving, facial transplantation is life-changing. This difference has generated ethical concerns about the exposure of otherwise young and healthy individuals to the sequelae of lifelong, high-dose, multidrug immunosuppression. Nevertheless advances in immunomodulatory and immunosuppressive protocols, microsurgical techniques, and computer-aided surgical planning have enabled broader clinical application of this procedure to patients. Although episodes of acute skin rejection continue to pose a serious threat to face transplant recipients, all cases have been controlled with conventional immunosuppressive regimens, and no cases of chronic rejection have been reported.

\section{Introduction}

Composite facial defects lead to severe functional impairment and have detrimental effects on an individual's psyche and quality of life. Facial disfigurement significantly affects social interactions and one's perception of body image, predisposing to depression, discrimination, and disability in many patients. ${ }^{1-7}$ Normal facial anatomy is also needed for many functions including air humidification, mastication of food, production of intelligible speech, clear vision, and the opportunity for social reintegration. ${ }^{1,8-10}$

Conventional reconstructive techniques can fall short of restoring form and function to patients with complex facial deformity, often requiring numerous staged procedures to provide only suboptimal results. Facial transplantation is a single operation that can restore aesthetic and functional characteristics of the native face by giving ultimate expression to Sir Harold Gillies' principle of "replacing like with like" (figure 1). ${ }^{11}$

Unlike solid organ transplantation, which is potentially life-saving, facial transplantation is life-changing. The possible consequences of lifelong immunosuppression in otherwise healthy individuals-including cancer, metabolic disorders, opportunistic infections, and death-must therefore be carefully balanced to minimise risk and maximise benefit. ${ }^{10}$ Yet, surgical innovation has outpaced the scientific community's ability to fully address certain immunological and clinical challenges. Here, we review the immunological, neurological, and anatomical principles gleaned from the 9 years since the first facial transplantation with a discussion of ethical considerations, highlighting lessons learned from clinical experience.

\section{Immunological principles}

Immunosuppressive strategies

Of the 28 facial transplants done to date (table 1), details of the immunosuppression strategy and outcomes have been published for 18.,.$^{910,12-38}$ Most recipients-but not all $14,23,39$ - had no panel-reactive antibodies. One patient who had $98-99 \%$ was treated with protein A immunoadsorption to $5 \%$ before transplantation. ${ }^{23}$ Antithymocyte globulin was used for induction for all but two patients, who instead received humanised anti-interleukin 2 postoperatively on days 0,15 , and 30 , and alemtuzumab intraoperatively. ${ }^{18,23}$ Steroid bolus and taper was used for all patients, progressing to lower steroid maintenance doses. Steroids were eventually withdrawn for four patients at 7 weeks, ${ }^{39} 8$ weeks, ${ }^{39}$ 22 weeks, $^{23}$ and 51 weeks. $^{40}$ An antimetabolite (mycophenolate mofetil) was used uniformly, and was discontinued per protocol for one patient. ${ }^{36}$ All protocols used calcineurin inhibitors consisting of tacrolimus at the outset, a goal of $10-15 \mathrm{ng} / \mathrm{mL}$ in an initial period of 1-5 months and in most cases lowering to a maintenance dose of $8-10 \mathrm{ng} / \mathrm{mL}$. The exception to this initial regimen had a tacrolimus target of $20-25 \mathrm{ng} / \mathrm{mL}$ for the first 15 months, decreasing to $10-15 \mathrm{ng} / \mathrm{mL}$ maintenance. ${ }^{23}$

Additional immunosuppressive strategies included irradiation of the graft in one patient, ${ }^{23}$ extracorporeal photopheresis for at least four patients, ${ }^{19,25}$ and IgG infusion per protocol for one patient ${ }^{23}$ and during discontinuation of tacrolimus and sirolimus for thrombotic microangiopathy in another. ${ }^{19}$ Vascularised bone marrow was present in 16 of 24 patients with details available. Donor iliac crest bone marrow cell infusion was additionally used for three patients. ${ }^{17,27}$ Sentinel flaps were used for four patients, ${ }^{17}$ and bilateral hands transplanted for two. ${ }^{16}$

\section{Immunological outcomes}

All face transplantation recipients have had an acute rejection episode of variable severity within the first year of transplantation., ${ }^{94}$ At least 11 patients had a single grade 1 episode,,$^{14,25}$ while five others had progressive episodes of acute grades 1-3 rejection..$^{38}$ One recipient had presumed grade 4 rejection leading to death. ${ }^{22}$ One other recipient with high panel-reactive antibodies had acute antibody-mediated grade 3 rejection in the first week after a positive cross-match. ${ }^{42}$ Few descriptions of rejection episodes after 1 year are available, probably because of-at least partly-little follow-up time. They include two patients, ${ }^{14,23}$ one of whom was repeatedly non-compliant with immunosuppression. $^{23}$ Another recipient was treated for histopathological evidence of grade 3 rejection in the oral mucosa without any evidence of rejection in the skin. ${ }^{36}$ Rosacea developed in one graft and mimicked
Lancet 2014; 384: 2153-63 Published Online April 28, 2014 http://dx.doi.org/10.1016/ S0140-6736(13)62632-X

Division of Plastic and Reconstructive Surgery, R Adams Cowley Shock Trauma Center (S Khalifian BA, PS Brazio MD, R Mohan MD, ( Shaffer MBA), Division of Transplant Surgery (R N Barth MD), University of Maryland Medical Center, Baltimore, MD, USA; Department of Plastic and Reconstructive Surgery, Reconstructive Transplantation Program, Johns Hopkins University School of Medicine, Baltimore, MD, USA (S Khalifian, G Brandacher MD); and Department of Plastic Surgery, Institute of Reconstructive Plastic Surgery, NYU Langone Medical Center, New York, NY USA (Prof E D Rodriguez MD)

Correspondence to:

Prof Eduardo D Rodriguez, NYU Langone Medical Center, 307 East 33rd Street, New York, NY 10016, USA eduardo.rodriguez@nyumc. org 
acute rejection until successful treatment with topical metronidazole..$^{34,43}$

Rejection episodes have generally been readily reversible with pulse dose corticosteroids, augmented in some cases by topical drugs (steroids $s^{17,36}$ and tacrolimus ${ }^{17}$ ). Other treatments have included increasing the tacrolimus target trough level, ${ }^{23}$ topical drugs alone, ${ }^{34}$ and observation ${ }^{12}$ for
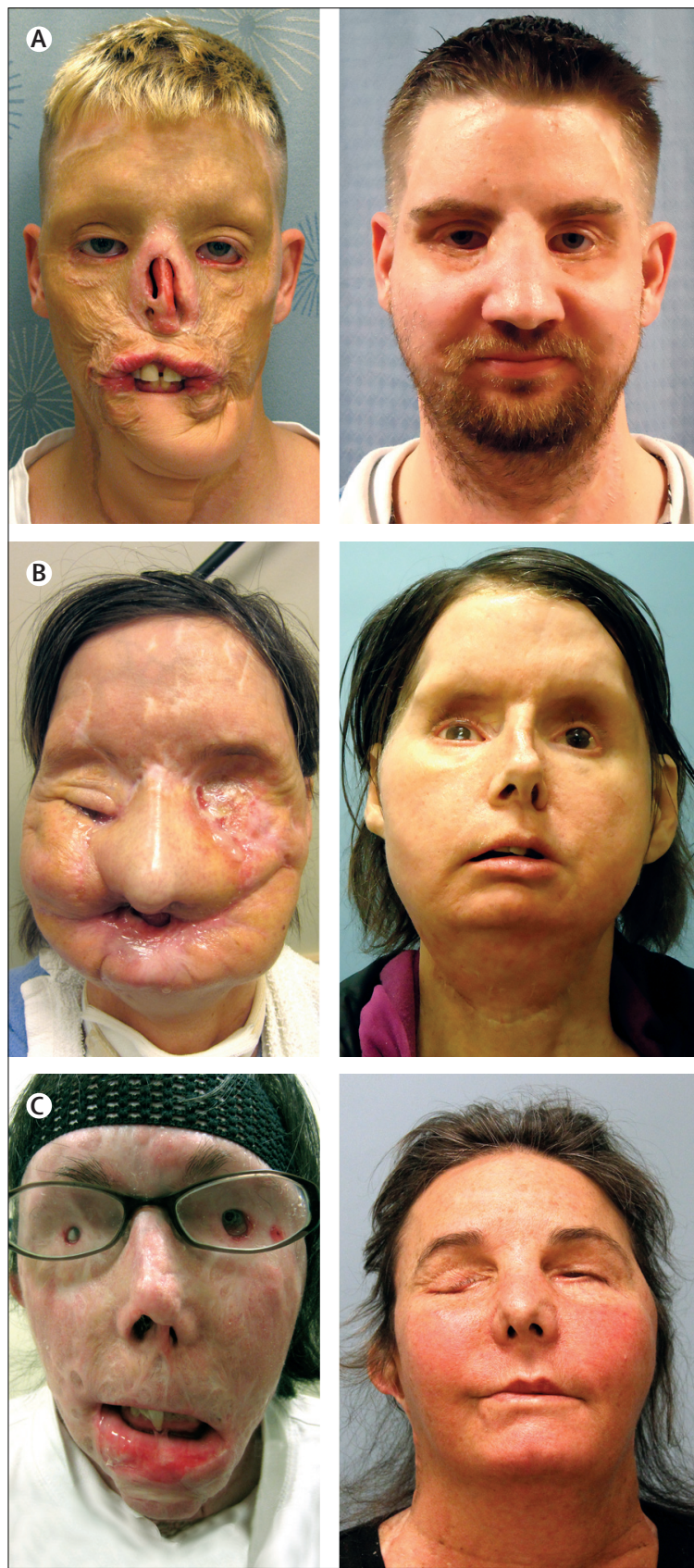

Figure 1: Outcomes of three facial transplantations

Preoperative (left) and postoperative images (right) showing the extraordinary restorative capacity of facial transplantation. Postoperative images represent patient outcomes at 18 months (A), 18 months (B), and 9 months (C). Credit: Bohdan Pomahac, Brigham and Women's Hospital. grade 1 rejection; addition of topical drugs for grade 2 rejection; and addition of plasmapheresis, eculizumab, bortezomib, ${ }^{42}$ and induction drugs such as anti-thymocyte globulin $^{12}$ and alemtuzumab ${ }^{42}$ for grade 3 rejection. One patient had to be switched from mycophenolate mofetil to sirolimus (in addition to tacrolimus and steroids) for nonresolving grade $2-3$ rejection. ${ }^{12}$

Chronic rejection or chronic allograft vasculopathy have not been reported; these disorders were previously considered possible and have become evident in human hand transplantation ${ }^{44}$ and preclinical studies. ${ }^{45}$ Hyperacute rejection from pre-formed antibodies has also not been reported. Donor-derived macrochimerism has not been reported. Microchimerism up to $0.6 \%$ was present in peripheral blood and bone marrow samples from one patient who received vascularised and infused bone marrow. ${ }^{27}$

Infectious complications have been common, occurring in at least 11 patients. Cytomegalovirus mismatches in six patients s,15,21,32,39 $^{1 e d}$ to ganciclovirresistant and valganciclovir-resistant infection in two patients $^{21,25}$ with asymptomatic seropositivity in another. ${ }^{15}$ Bacterial infection at the site of operation was reported in three patients (one of whom was co-infected with Candida) $)^{39}$ and systemically in five. Leucopenia was reported in two patients and treated by reduced immunosuppression and filgrastim. ${ }^{14,36}$ Both recipients of simultaneous upper extremity transplants developed sepsis: ${ }^{16}$ one from aspiration pneumonia, leading to bilateral extremity graft loss with salvage of the face, ${ }^{39}$ and one from a pseudomonal graft infection at day 12 after surgery that led to cardiac arrest and death. ${ }^{25}$

Of two recipients who were mismatched for EpsteinBarr virus, ${ }^{15,29}$ one developed a monoclonal B-cell lymphoma at 4 months requiring rituximab and reduction of immunosuppression. ${ }^{29}$ No graft-versus-host disease has been reported. Chronic renal insufficiency has been reported in two patients, ${ }^{14,19}$ one of whom had to be switched from calcineurin inhibitor to sirolimus at 11 months for chronic renal insufficiency, which resolved after treatment for thrombotic microangiopathy that followed treatment conversion. ${ }^{19}$ New-onset diabetes developed in two recipients ${ }^{23,34}$ (one of whom received prolonged high-dose tacrolimus treatment). A third patient needed to be given insulin. ${ }^{39}$ Two recipients had to change from mycophenolate mofetil to mycophenolic acid for gastrointestinal adverse effects. ${ }^{34,39}$ Two instances of postoperative delirium were attributed to steroid induction. ${ }^{14,22}$ The third confirmed death after face transplantation was the result of tumour recurrence in an HIV-positive patient who had previously undergone cancer resection. ${ }^{46}$

\section{Immunological challenges and future directions}

Face transplantation using depletional induction and a standard three-drug immunosuppression regimen results in acceptable immunological outcomes. 


\begin{tabular}{|c|c|c|c|c|c|c|c|c|}
\hline & Date & Location & $\begin{array}{l}\text { Surgical } \\
\text { team }\end{array}$ & $\begin{array}{l}\text { Recipient } \\
\text { details }\end{array}$ & Cause & $\begin{array}{l}\text { Extent of } \\
\text { defect }\end{array}$ & $\begin{array}{l}\text { Functional } \\
\text { deficit }\end{array}$ & $\begin{array}{l}\text { Allograft } \\
\text { type }\end{array}$ \\
\hline 1 & November, 2005 & Amiens, France & $\begin{array}{l}\text { Devauchelle } \\
\text { and Dubernard }\end{array}$ & Female, age 38 years & Dog bite & Cheek, nose, lips, chin & $\begin{array}{l}\text { Labial competence, } \\
\text { speech }\end{array}$ & Partial \\
\hline 2 & April, 2006 & Xi'an, China & Guo & Male, age 30 years & Bear bite & $\begin{array}{l}\text { Cheek, nose, upper lip, maxilla, orbital wall, } \\
\text { zygoma }\end{array}$ & & Partial \\
\hline 3 & January, 2007 & Paris, France & Lantieri & Male, age 29 years & Neurofibromatosis & Forehead, brows, eyelids, nose, lips, cheeks & $\begin{array}{l}\text { Labial competence, } \\
\text { speech }\end{array}$ & Partial \\
\hline 4 & December, 2008 & Cleveland, OH, USA & Siemionow & Female, age 45 years & Ballistic trauma & $\begin{array}{l}\text { Lower eyelids, nose, upper lip, orbital floor, } \\
\text { zygoma, maxilla }\end{array}$ & Speech, eating & Partial \\
\hline 5 & March, 2009 & Paris, France & Lantieri & Male, age 27 years & Ballistic trauma & Nose, lips, maxilla, mandible & $\begin{array}{l}\text { Labial competence, } \\
\text { speech }\end{array}$ & Partial \\
\hline 6 & April, 2009 & Paris, France & Lantieri & Male, age 37 years & Third degree burn & Forehead, nose, eyelids, ears, cheek & Blink & Partial \\
\hline 7 & April, 2009 & Boston, MA, USA & Pomahac & Male, age 60 years & Electrical burn & $\begin{array}{l}\text { Lower eyelid, cheek, nose, lips, maxilla, } \\
\text { zygoma }\end{array}$ & $\begin{array}{l}\text { Labial competence, } \\
\text { speech }\end{array}$ & Partial \\
\hline 8 & August, 2009 & Paris, France & Lantieri & Male, age 33 years & Ballistic trauma & Cheek, nose, lips, maxilla, mandible & $\begin{array}{l}\text { Labial competence, } \\
\text { speech }\end{array}$ & Partial \\
\hline 9 & August, 2009 & Valencia, Spain & Cavadas & Male, age 42 years & Cancer & $\begin{array}{l}\text { Lower lip, tongue, floor of mouth, } \\
\text { mandible }\end{array}$ & $\begin{array}{l}\text { Labial competence, } \\
\text { speech }\end{array}$ & Partial \\
\hline 10 & November, 2009 & Amiens, France & $\begin{array}{l}\text { Devauchelle } \\
\text { and Dubernard }\end{array}$ & Male, age 27 years & Ballistic trauma & Nose, lips, mandible & $\begin{array}{l}\text { Labial competence, } \\
\text { speech }\end{array}$ & Partial \\
\hline 11 & January, 2010 & Seville, Spain & Gomez-Cia & Male, age 35 years & Neurofibromatosis & Cheek, lips, chin, mandible & $\begin{array}{l}\text { Labial competence, } \\
\text { speech }\end{array}$ & Partial \\
\hline 12 & March, 2010 & Barcelona, Spain & Barrett & Male, age 30 years & Ballistic trauma & $\begin{array}{l}\text { Eyelids, nose, lips, lacrimal apparatus, } \\
\text { zygoma, maxilla, mandible }\end{array}$ & $\begin{array}{l}\text { Labial competence, } \\
\text { speech }\end{array}$ & Full \\
\hline 13 & June, 2010 & Paris, France & Lantieri & Male, age 35 years & Neurofibromatosis & Eyelids, ears, nose, lips, oral mucosa & Blink, speech & Full \\
\hline 14 & March, 2011 & Boston, MA, USA & Pomahac & Male, age 25 years & Electrical burn & Forehead, eyelids, left eye, nose, cheek, lips & Blink, speech & Full \\
\hline 15 & April, 2011 & Paris, France & Lantieri & Male, age 45 years & Ballistic trauma & Nose, mandible, maxilla & Speech & Partial \\
\hline 16 & April, 2011 & Paris, France & Lantieri & Male, age 41 years & Ballistic trauma & Nose, mandible, maxilla & Speech & Partial \\
\hline 17 & April, 2011 & Boston, MA, USA & Pomahac & Male, age 30 years & Electrical burn & Forehead, eyelids, nose, cheek, lips & $\begin{array}{l}\text { Labial competence, } \\
\text { speech }\end{array}$ & Full \\
\hline 18 & May, 2011 & Boston, MA, USA & Pomahac & Female, age 57 years & Animal attack & $\begin{array}{l}\text { Forehead, eyelids, eyes, nose, lips, maxilla, } \\
\text { mandible }\end{array}$ & Blink, speech & Full \\
\hline 19 & January, 2012 & Ghent, Belgium & Blondeel & Male & Industrial accident & .. & .. & Partial \\
\hline 20 & January, 2012 & Antalya, Turkey & Ozkan & Male, age 45 years & Burn & .. & .. & Full \\
\hline 21 & February, 2012 & Ankara, Turkey & Nasir & Male, age 25 years & Burn & .. & .. & Full \\
\hline 22 & March, 2012 & Ankara, Turkey & Ozmen & Female, age 20 years & Ballistic trauma & Nose, upper lip, chin, maxilla & .. & Partial \\
\hline 23 & March, 2012 & Baltimore, MD, USA & Rodriguez & Male, age 37 years & Ballistic trauma & $\begin{array}{l}\text { Forehead, eyelids, nose, cheek, lips, } \\
\text { zygoma, maxilla mandible }\end{array}$ & Speech, blink & Full \\
\hline 24 & May, 2012 & Antalya, Turkey & Ozkan & Male, age 34 years & Burn & .. & .. & Full \\
\hline 25 & September, 2012 & Amiens, France & $\begin{array}{l}\text { Devauchelle } \\
\text { and Dubernard }\end{array}$ & Female & Vascular tumour & .. & .. & .. \\
\hline 26 & February, 2013 & Boston, MA, USA & Pomahac & Female, age 44 years & Chemical burn & $\begin{array}{l}\text { Nose, lips, eyelids, forehead, cheek, ears, } \\
\text { eyes }\end{array}$ & .. & Full \\
\hline 27 & May, 2013 & Gliwice, Poland & Maciejewski & Male, age 33 years & Blunt trauma & Nose, lips, eyelid, cheek & Speech & Partial \\
\hline 28 & July, 2013 & Antalya, Turkey & Ozkan & Male, age 27 years & Ballistic trauma & $\begin{array}{l}\text { Forehead, eyelids, left eye, nose, cheek, } \\
\text { maxilla, mandible }\end{array}$ & .. & Full \\
\hline
\end{tabular}

Concurrent upper extremity transplantation, recipients with high concentrations of panel-reactive antibodies, and serological matching continue to present challenges. The three patient deaths that have occurred reinforce the importance of patient selection for potential noncompliance and underlying medical comorbidities. As expected from experiences of solid organ transplantation, serological mismatch often leads to infectious and oncological complications and should either be avoided (eg, Epstein-Barr virus) or pre-emptively treated (eg, cytomegalovirus). We believe that it is crucial to avoid giving cytomegalovirus-positive grafts to cytomegalovirus-negative recipients, because it can be life threatening and can trigger acute rejection. ${ }^{47-50}$

Although sentinel flaps might decrease confounding environmental effects on histopathological and clinical analysis, their use for face transplantation is unclear: many patients without sentinel flaps have had successful 
immunosuppression. The mucosa-although used in a few cases for pathological diagnosis of rejection-is not addressed by the Banff classification. ${ }^{51}$ More importantly, its continuous exposure to low-grade trauma and high antigen loads from food and bacterial flora is likely to cause more confounding than the local graft skin. Nevertheless, episodes of sentinel flap rejection seem to correspond with face transplantation rejection, and sentinel flaps might be useful for patients with little facial skin for biopsies.

Episodes of mild rejection might be more likely to be treated in face transplantation than in solid organ transplantation because of the skin's immediate visibility. This effect could lead to over-treatment of mild rejection and exacerbation of infectious complications; the single reported instance of observation for grade 1 rejection resulted in spontaneous resolution. However, the prompt correction of even mild rejection might be one reason for the absence of chronic rejection in patients who have had face transplantation. Nevertheless, patients are advised to avoid mechanical trauma and environmental injury to the allograft-eg, excessive sun exposure. Such events could precipitate acute rejection episodes, which increase the chances of chronic allograft deterioration and vasculopathy. ${ }^{32,52}$

Because the reporting of outcomes is not standardised, it is impossible to correlate any treatment (including vascularised or infused bone marrow, induction, or maintenance) with the incidence of rejection. Adjunctive cellular treatments, although promising in small animal models, do not seem to promote tolerance or induce chimerism in the absence of depletional preconditioning. A centralised database with standardised reporting intervals, compliant with local and national regulations, and accessible to all contributors, would greatly accelerate the advancement of clinical science in vascularised composite allotransplantation.

\section{Neurological principles \\ Sensory nerves}

Before the first face transplantation in 2005, restoration of normal facial sensation was thought to be unlikely. ${ }^{41}$ This assumption has not been borne out by clinical experience over the past decade: rapid restoration of sensory feedback has been reported consistently (table 2). Thermal and mechanical sensation can occur as early as 3 months after surgery, ${ }^{26,39}$ with satisfactory sensory restoration often by 8 months (as defined by recovery of heat and cold sensation, discrimination of light touch assessed by static monofilament, well localised two-point touch discrimination, and response to painful stimuli). ${ }^{19,25,26,39}$

The operational strategy used to repair sensory nerves differs between centres. Nevertheless, sensory recovery has occurred independent of nerve repair. An argument has been made for neurorrhaphy of all major sensory nerves after one recipient had anaesthesia at 4 months on the side that did not undergo neurorrhaphy, while the side that did was concurrently sensate. ${ }^{39}$ Similarly, direct endto-end mental and infraorbital neurorrhaphy has resulted in thermal sensation recovery by 2 weeks and response to painful and thermal stimuli throughout the entire allograft by 14 weeks. ${ }^{1719}$ Conversely, simple placement of bilateral donor mental nerves near the mental foramen without neurorrhaphy has produced good sensory outcomes by 3 months. ${ }^{26}$ Restoration of sensation can occur without any repair of the trigeminal nerve by 6 months, ${ }^{14}$ similar to outcomes from Cleveland and Paris. ${ }^{25,37}$ Thus, recovery of satisfactory facial sensation can be obtained in patients with extensive nerve damage without neurorrhaphy; however, further studies are needed to clearly assess the role of neurorrhaphy in affecting the rate, integrity, and topography of facial sensory reinnervation.

Several causes of sensory restoration for patients who have not had trigeminal nerve repair have been suggested. These include recipient and donor characteristics, immunosuppressive side-effects, and various alternative pathways for afferent nerve conduction. ${ }^{53}$ The human face has more than 17000 corpuscles that contribute to various sensory functions, and many of these are probably retained within the allograft. ${ }^{54}$ Furthermore, the location of the recipient site affects the outcome of sensory recovery: sensation is recovered better in the orofacial region than in the trunk and lower extremities. ${ }^{55-57} \mathrm{We}$ suggest that this effect might be partly explained by higher cortical representation of the face. ${ }^{58}$

A beneficial side-effect of immunosuppression with tacrolimus is the dose-dependent acceleration of axonal regeneration, as reported previously for limb allografts. ${ }^{59}$ Tacrolimus reduces neuronal recovery time of nerve lesion repair by $50 \%$, increases number of myelinated axons by $40 \%$, doubles the number of regenerating axons after nerve injury, and increases myelin thickness and sprouting of peripheral nerve fibres. ${ }^{60-62}$ Pathways for sensory recovery in patients without trigeminal nerve repair include trigeminofacial communications, somatic afferents of the facial nerve, and the adrenergic fibres surrounding the allograft's vascular pedicle. ${ }^{58}$ Sensory return paralleled the recovery of the facial nerve in one patient, which could be a result of afferent fibres in the communicating rami between the facial and trigeminal nerves contributing to sensation in the absence of trigeminal nerve signalling. ${ }^{58}$

\section{Motor nerves}

Restoration of motor function is dependent on facial nerve coaptation and has generally been slower than sensory reinnervation. Motor recovery typically occurs by $6-8$ months, with ongoing improvements in the subsequent years. ${ }^{9}$ With coaptation, lip occlusion can occur by 6 months ${ }^{19}$ and complete mouth closure by 8 months, ${ }^{26}$ although initial motor recovery was reported even earlier (table 2 ). In the long term, recovery of the ability to smile has been noted as late as 2 years after transplantation, ${ }^{63}$ and continuing improvements have occurred as late as 8 years after 


\begin{tabular}{|c|c|c|c|c|}
\hline & Sensory recovery & Motor recovery & Functional recovery & Psychological recovery \\
\hline 1 & $\begin{array}{l}\text { Light touch at } 14 \text { weeks, } \\
\text { thermal at } 6 \text { months }\end{array}$ & $\begin{array}{l}\text { Lip occlusion at } 6 \text { months, contractions of chin } \\
\text { and nose muscles at } 12 \text { months }\end{array}$ & $\begin{array}{l}\text { Mobile food bolus at } 6 \text { months, } \\
\text { symmetrical smile at } 18 \text { months }\end{array}$ & Social reintegration at 3 months \\
\hline 2 & $\begin{array}{l}\text { Light touch at } 3 \text { months, } \\
\text { thermal at } 8 \text { months }\end{array}$ & Poor function of muscles of facial expression & $\begin{array}{l}\text { Able to eat, drink, and speak at } 2 \text { years, } \\
\text { unable to smile symmetrically }\end{array}$ & $\begin{array}{l}\text { Transplant well tolerated, accepted new face } \\
\text { easily with improved body image }\end{array}$ \\
\hline 3 & $\begin{array}{l}\text { Light touch at } 3 \text { months, } \\
\text { thermal at } 3 \text { months }\end{array}$ & $\begin{array}{l}\text { Motor recovery confirmed by electromyogram at } \\
12 \text { months }\end{array}$ & Not reported & $\begin{array}{l}\text { Objective improvement in quality of life, } \\
\text { returned to work at } 13 \text { months }\end{array}$ \\
\hline 4 & $\begin{array}{l}\text { Light touch at } 6 \text { months, } \\
\text { thermal not reported }\end{array}$ & Progressive recovery at 8 months & $\begin{array}{l}\text { Able to eat, drink, smell, and speak at } \\
8 \text { months, reduction in chronic pain }\end{array}$ & $\begin{array}{l}\text { Objective improvement in quality of life, } \\
\text { body image, and depression }\end{array}$ \\
\hline 5 & $\begin{array}{l}\text { Light touch (partial deep pressure) at } \\
8 \text { months, thermal absent at } 17 \text { months }\end{array}$ & $\begin{array}{l}\text { Recovery of orbicularis oris at } 2 \text { months (left) and } \\
3 \text { months (right) }\end{array}$ & Complete mouth closure at 8 months & $\begin{array}{l}\text { Objective improvement in quality of life } \\
\text { and body image, returned to work at } 18 \text { months }\end{array}$ \\
\hline 6 & Not reported & Not reported & Not reported & $\begin{array}{l}\text { Objective improvement in quality of life } \\
\text { and body image }\end{array}$ \\
\hline 7 & $\begin{array}{l}\text { Light touch at } 6 \text { months, } \\
\text { thermal at } 6 \text { months }\end{array}$ & $\begin{array}{l}\text { Progressive recovery at } 12 \text { months with motor } \\
\text { control of lips and symmetrical smile }\end{array}$ & $\begin{array}{l}\text { Able to speak, smell, and breath through } \\
\text { nose immediately, able to eat by day } 3 \text {, } \\
\text { unable to pucker lips at } 12 \text { months }\end{array}$ & $\begin{array}{l}\text { Early social reintegration by } 5 \text { weeks with } \\
\text { improved body image, no psychiatric events } \\
\text { reported at 3-year follow-up }\end{array}$ \\
\hline 8 & $\begin{array}{l}\text { Light touch absent at } 12 \text { months, } \\
\text { thermal absent at } 12 \text { months }\end{array}$ & $\begin{array}{l}\text { Recovery of left zygomatic and orbicularis oris } \\
\text { muscles at } 5 \text { months, absent on right at } 12 \text { months }\end{array}$ & Complete mouth closure at 12 months & $\begin{array}{l}\text { Objective improvement in quality of life } \\
\text { and body image }\end{array}$ \\
\hline 9 & Not reported & Mandible excursion $10 \mathrm{~mm}$ at 16 months & Swallowing and phonation at 16 months & Not reported \\
\hline 10 & Not reported & Not reported & Not reported & Patient satisfied with body image at 20 months \\
\hline 11 & $\begin{array}{l}\text { Light touch at } 6 \text { months, } \\
\text { thermal at } 6 \text { months }\end{array}$ & $\begin{array}{l}\text { Progressive recovery with satisfactory control of } \\
\text { buccinator and levator labii confirmed by } \\
\text { electromyogram at } 6 \text { months }\end{array}$ & Able to speak and eat by 6 months & No psychiatric problems reported at 6 months \\
\hline 12 & $\begin{array}{l}\text { Light touch at } 4 \text { months, } \\
\text { thermal at } 4 \text { months }\end{array}$ & $\begin{array}{l}\text { Satisfactory facial expression at } 4 \text { months, } \\
\text { reinnervation confirmed by electromyogram }\end{array}$ & $\begin{array}{l}\text { Full masticatory motion at } 4 \text { months, } \\
\text { limited eye closure at } 4 \text { months }\end{array}$ & $\begin{array}{l}\text { Patient satisfied with body image at } 4 \text { months, } \\
\text { no psychiatric problems reported at } 1 \text { year }\end{array}$ \\
\hline 13 & Full sensory recovery after 6 months & $\begin{array}{l}\text { Progressive motor recovery, zygomatic muscle } \\
\text { contraction (left) at } 12 \text { months, absent on right }\end{array}$ & Complete mouth closure at 12 months & $\begin{array}{l}\text { Objective improvement in quality of life and } \\
\text { body image, returned to work at } 6 \text { months }\end{array}$ \\
\hline 14 & $\begin{array}{l}\text { Return of sensation to right side } \\
\text { but not left side of face at } 4 \text { months }\end{array}$ & Movement of right side of face at 4 months & Not reported & $\begin{array}{l}\text { Objective improvement in quality of life } \\
\text { and mental health at } 6 \text { months }\end{array}$ \\
\hline 15 & Not reported & Not reported & Not reported & Not reported \\
\hline 16 & Not reported & Not reported & Not reported & Not reported \\
\hline 17 & $\begin{array}{l}\text { Return of sensation to chin and } \\
\text { forehead at } 3 \text { months }\end{array}$ & Return of lip motion at 3 months & Not reported & $\begin{array}{l}\text { Objective improvement in quality of life } \\
\text { and mental health at } 6 \text { months }\end{array}$ \\
\hline 18 & $\begin{array}{l}\text { Return of sensation to entire } \\
\text { allograft at } 3 \text { months }\end{array}$ & No return of motor function at 3 months & Not reported & $\begin{array}{l}\text { Objective improvement in quality of life } \\
\text { and mental health at } 6 \text { months }\end{array}$ \\
\hline 19 & Not reported & Not reported & Able to drink and speak at 6 days & Not reported \\
\hline 20 & Not reported & Not reported & Not reported & Not reported \\
\hline 21 & Not reported & Not reported & Not reported & Not reported \\
\hline 22 & Not reported & Not reported & Not reported & Not reported \\
\hline 23 & $\begin{array}{l}\text { Light touch at } 6 \text { months, } \\
\text { thermal at } 6 \text { months }\end{array}$ & $\begin{array}{l}\text { Initial motor recovery at } 2 \text { months, lip occlusion } \\
\text { at } 6 \text { months, progressive motor recovery }\end{array}$ & $\begin{array}{l}\text { Able to form food bolus, swallow, } \\
\text { and speak at } 3 \text { months }\end{array}$ & $\begin{array}{l}\text { Social reintegration by } 8 \text { weeks, objective } \\
\text { improvement in quality of life, body image, and } \\
\text { depression, no psychiatric events at } 18 \text { months }\end{array}$ \\
\hline 24 & Not reported & Not reported & Able to speak at 15 days & Not reported \\
\hline 25 & Not reported & Not reported & Not reported & Not reported \\
\hline 26 & Not reported & Not reported & Not reported & Not reported \\
\hline 27 & Not reported & Not reported & Not reported & Not reported \\
\hline 28 & Not reported & Not reported & Not reported & Not reported \\
\hline
\end{tabular}

surgery. Initial motor recovery can occur by 3 months, with complete lip occlusion by 6 months, ${ }^{19}$ and ongoing improvements at 1 year. ${ }^{26}$ We did tongue transplantation without hypoglossal nerve coaptation to the tongue to avoid compromising the patient's baseline tongue function. Nevertheless, the ability to form food boluses, swallow, and produce intelligible speech was restored by 3 months. In such a scenario, end-to-side hypoglossal nerve coaptation might help to accelerate and integrate motor function in donor tissues, although further comparative studies are needed to elucidate how such a procedure might affect functional outcomes. However, unlike sensory nerves, restoration of motor function seems to depend on neurorrhaphy, as evidenced by poor motor function and lack of gradual improvement in a patient with unsatisfactory facial nerve coaptation. ${ }^{23}$

Nerve repair in face transplantation is difficult: neural structures are often damaged, atrophic, or hypertrophic, 

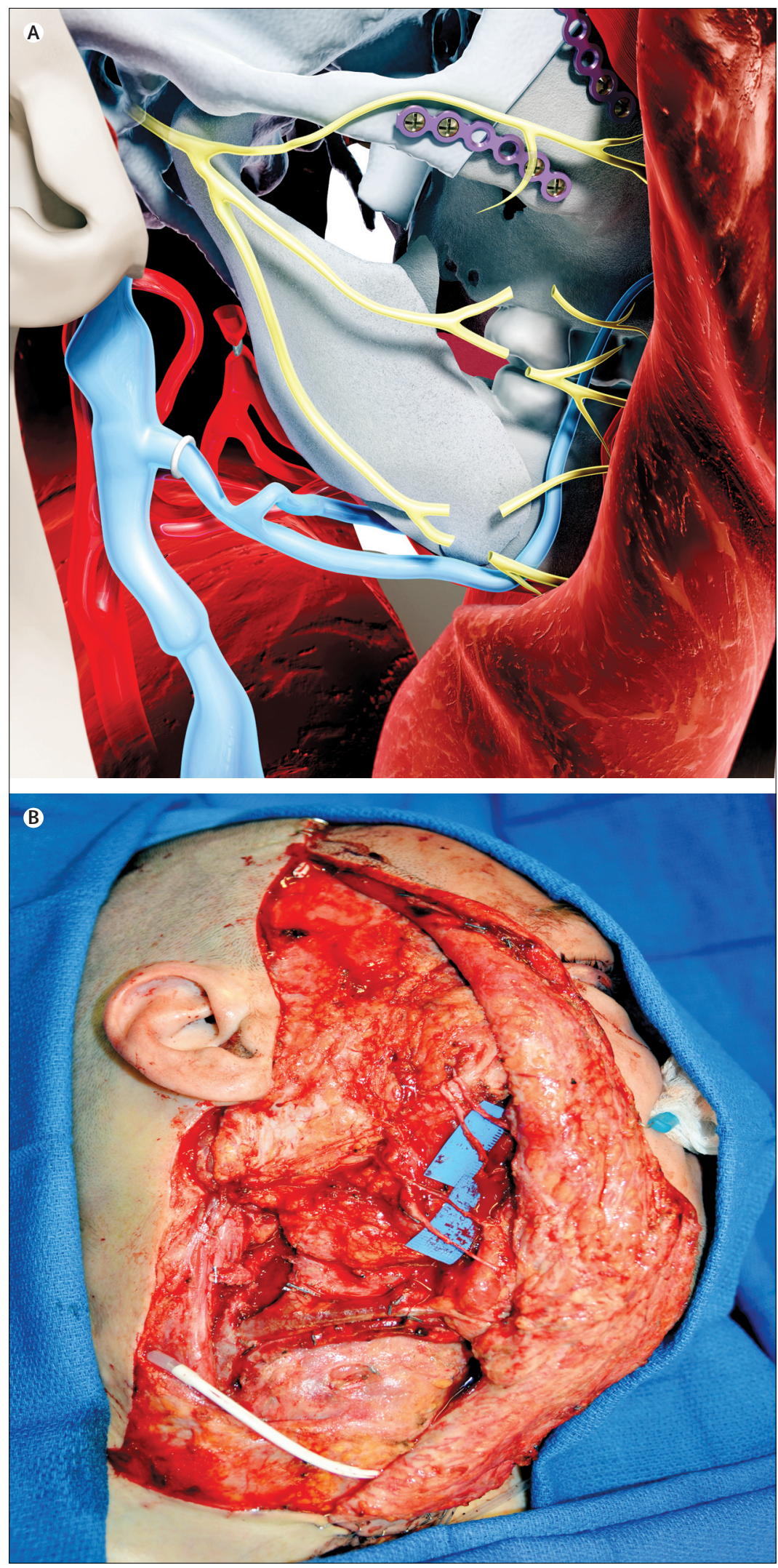

either because of the initial injury or scarring from previous reconstruction and salvage attempts. ${ }^{1}$ The approach used to repair nerves varies by institution, but one general principle is that facial nerve coaptation should be done as close as possible to target muscles to optimise outcomes and minimise unpredictable reinnervation and synkinesis (figure 2) ${ }^{64}$ Although facial nerve coaptation close to the main trunk increases capacity for facial expression and movement as a result of greater control of the target muscles, ${ }^{25}$ it risks damaging any intact motor nerve function (eg, blinking). Previous experience shows that motor recovery is accelerated when distal nerve repair is done as opposed to proximal isolation of the main trunk of the facial nerve. . $7,19,25,26,35,37,39,41,65$

\section{Functional outcomes}

Recovery of facial movements and function has been favourable after face transplantation, with improved ability to eat, drink, speak, smell, and smile in almost all patients. ${ }^{9,1926,35,37,39,41}$ Functional improvements have paralleled motor recovery, with restoration to almost normal functional capacity. ${ }^{33}$ Recovery of intelligible speech was reported for four patients within 1 month of transplantation, ${ }^{25}$ and significant improvement in swallowing, breathing, and smell immediately after surgery was reported for another. ${ }^{34}$ Even without satisfactory facial nerve coaptation, recovery of the ability to speak, drink, and eat normally by 2 years has been noted. ${ }^{23}$ The use of interpositional nerve grafts for facial nerve coaptation led to restoration of function by 8 months after transplantation, with a significant reduction of chronic pain caused by scarred and contracted tissues from eight of ten before transplantation to one of ten after transplantation according to patient's self-report. ${ }^{37}$ Functional outcomes can be similar, with tracheostomy decannulation at 12 months following 15 years of dependence (unpublished).

The rate of sensory, motor, and functional recovery is contingent on adherence to the immunosuppressive regimen, and some clinicians contend that an early, aggressive rehabilitation programme might help to improve allograft function. ${ }^{6}$ At present, the effect of aggressive rehabilitation for improvement of allograft function is unclear: spontaneous use of facial musculature has been reported for some patients shortly after transplantation irrespective of participation in such programmes. ${ }^{34,39}$ Nevertheless, rehabilitation often begins as early as $48 \mathrm{~h}$ after surgery and includes speech therapy, range-of-motion exercises, and sensory re-education. ${ }^{66}$ These measures expedite cortical reorganisation in

Figure 2: Facial nerve coaptation for motor reanimation

(A) Three-dimensional modelling of distal facial nerve branches helps to plan the surgery. (B) Intra-operative image showing successful facial nerve coaptation, with distal branches of the patient's facial nerve sutured to the donor's facial nerve stumps. Coaptation is carried out as close as possible to target effector muscles in an effort to prevent dyskinesis. 


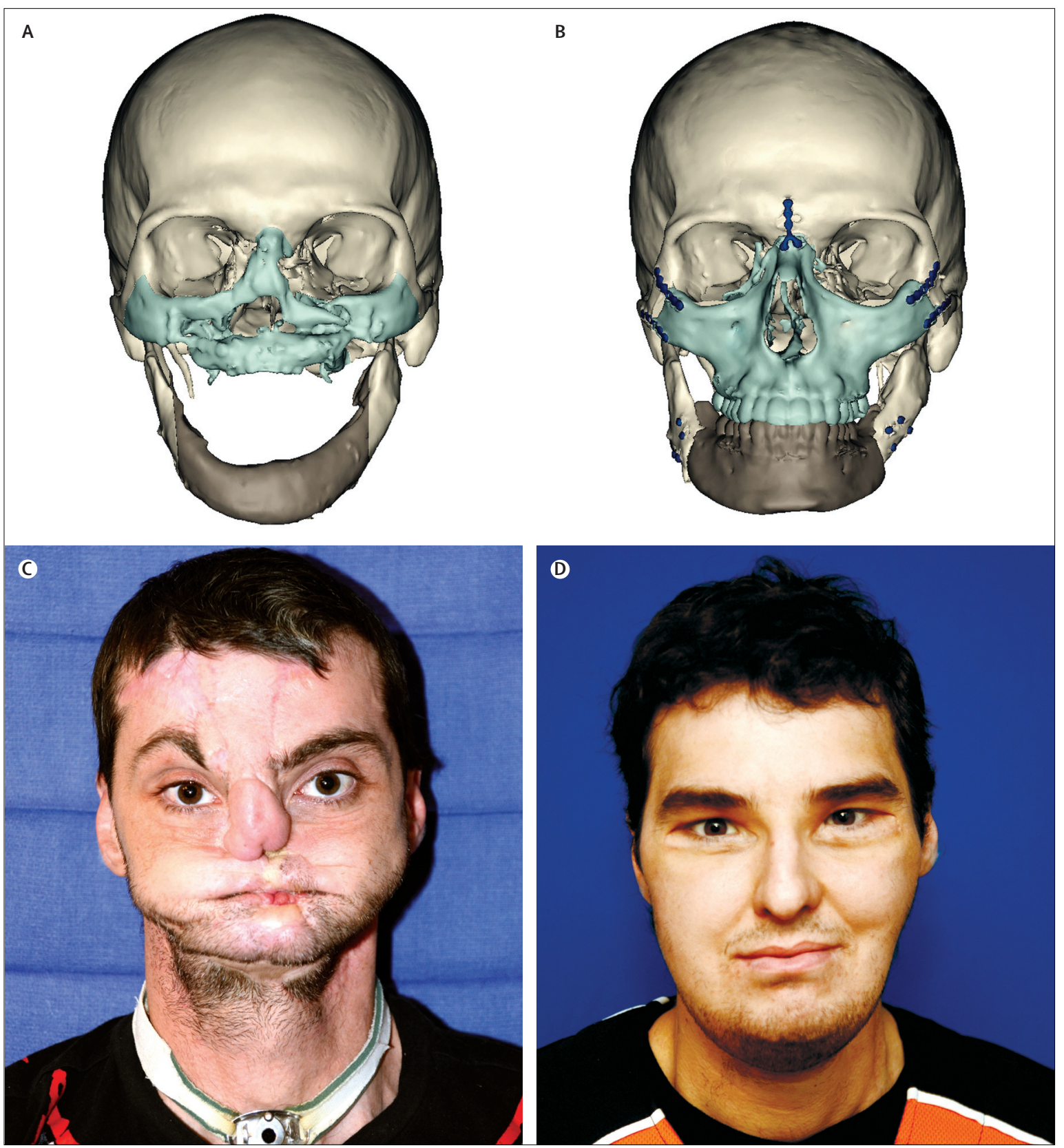

Figure 3: Use of computer-aided design and modelling to assist the preoperative planning of facial transplantation

Three-dimensional craniofacial CT scan reconstruction shows the patient's facial defect before (A) and after (B) facial allotransplantation. The entire midface and mandible-including the donor's teeth and tongue--were transplanted. Corresponding photographs of the patient before the operation (C) and 16 months after (D).

patients, promoting recognition and integration of the newly transplanted muscles into the patient's motor cortex. ${ }^{67}$ Such brain plasticity contributes to favourable outcomes after face transplantation. ${ }^{68}$ Vision is considered an important determinant of cortical reorganisation, reintegration, and ultimate functional outcome. Blindness has been considered by some to be a contraindication to face transplantation; ${ }^{69}$ however, a blind patient given a full face transplantation had promising functional outcomes at 1 year. ${ }^{39}$ Thus, the importance of patient motivation, rehabilitation, and adherence to immunosuppression cannot be overstated.

\section{Psychological outcomes}

Psychological outcomes for recipients of face transplants have been generally favourable. Initial concerns about feelings of depersonalisation towards the new face and donor identity transfer or split have not been substantiated, 
and recipients do not resemble donors according to donor families, recipients, and transplant teams. ${ }^{39,70}$ A review of psychological outcomes after face transplantation showed a decreased prevalence of depression and verbal abuse and significantly improved body image, sense of self, and social reintegration..$^{17,19,22,23,26,36,71}$ Patients have accepted their new face and describe improved quality of life, with several patients returning to work. 12,17,19,23,25,26,63

The overwhelmingly positive psychological outcome is probably a result of rigorous preoperative psychiatric and psychological selection of patients deemed to be stable, motivated, and compliant by a multidisciplinary team. ${ }^{66}$ The most notable exception is the patient whodispleased with the side-effects of immunosuppressive treatment-came to rely instead on traditional remedies on several occasions, leading to multiple rejection episodes and death. ${ }^{22}$ This outcome might have been prevented by more careful preoperative assessment and education, and postoperative psychiatric follow-up.

\section{Anatomical principles Post-transplantation revision}

As the number of face transplantations done has increased, the postoperative focus has expanded to include refining and optimising aesthetic and functional outcomes. ${ }^{18,72}$ Functional and aesthetic restoration can be assisted through several secondary procedures, including bone and dental realignment, soft-tissue resuspension and contouring, full-thickness skin grafting, fat injection, and dermabrasion. ${ }^{73,74}$ The goals of these revisionary procedures are to optimise functional outcomes, accentuate facial features disguised by bulky tissue, ensure proper colour and texture, and match thickness across the entirety of the face.

Revision of a facial allograft poses additional risks not encountered in conventional reconstructive surgery. Potential complications include increased susceptibility to infection and poor wound healing secondary to immunosuppression, ${ }^{75,76}$ complications of anaesthesia in an immunocompromised patient, ${ }^{\pi}$ and increased inflammation as a direct result of the revision, increasing the likelihood of acute rejection. ${ }^{78}$ The high cost of a negative outcome leads to an understandable reluctance to revise an otherwise successful allograft.

A face transplantation might not initially fulfil its promise of optimising form and function, tilting the riskbenefit balance in favour of revision despite the potential for complications. Several postoperative revisions have been described, including: excision of redundant skin; ${ }^{34}$ rotation, realignment, and re-occlusion of the maxilla; ${ }^{79}$ scar revision and tissue resuspension (Mohan $\mathrm{R}$, unpublished data); cartilage grafting for volume restoration; ${ }^{22}$ and dental implants to achieve optimal occlusion. ${ }^{22}$ Such revisions seem not to cause major complications including rejection ${ }^{26}$ and they might further reduce psychological morbidity by alleviating concerns about identity. ${ }^{80}$

\section{Bone and dental occlusion}

Correct occlusion of the jaws is a necessary condition for facial transplantation to restore form and function. Of 17 face transplants including either maxilla or mandible, only eight included the full maxilla and mandible. A hybrid occlusion between the jaws of two different individuals is necessary in these cases and an occlusion that is both functional and anatomically accurate is difficult to achieve at the time of transplantation..$^{81,82}$ For one patient, the maxilla and partial tooth-bearing mandible were transplanted, resulting in a partial donor and partial hybrid occlusion. ${ }^{83}$

The best hybrid occlusion can only partly recreate the functions of mastication and speech, even after tooth contouring. Use of hybrid occlusion might also further narrow an already small donor pool by imposing additional constraints on jaw morphology or dentition to better fit the opposite recipient jaw. We therefore advocate co-transplantation of the tooth-bearing segments of maxilla and mandible whenever possible, potentially even for defects of a single jaw. Although these additional procedures increase the duration and complexity of surgery, bimaxillary transplantation enables adequate occlusion constrained only by accuracy in placement.

Bimaxillary transplantation might not yield perfect occlusion even with preoperative computer-aided planning (figure 3; unpublished). This failure is probably a result of adjustments of the relation between the mandibular condyle and its fossa while under anaesthesia compared with conscious activity with displacement of the mandible by muscular activity. ${ }^{84}$ Refinements in technologies such as computer-assisted design and modelling, intraoperative navigation, and premanufactured cutting guides ${ }^{18}$ might further improve cutting and positioning of the facial skeleton.

One of the greatest imperatives when planning bony revisions is assessment of the vascular supply of the graft; whether earlier orthodontic management would avoid the need for skeletal revision is unclear, and the best approach to foreseeing or preventing these changes is still a matter of debate. Nevertheless, suboptimal occlusion can safely be corrected by revisionary midfacial osteotomies (unpublished).

\section{Ethical dilemmas}

The major ethical concerns about face transplantation are similar to the early ethical debates about hand transplantation. ${ }^{85}$ Because of the complexity of the procedure, and the unknown risks and benefits, the most important decision is still the selection of the candidate. The best candidate is one who: fully understands the implications of potentially lifelong immunosuppression and its serious morbidities, including infections, cancer, graft loss, and death; is motivated, committed, and compliant with intense post-operative rehabilitation, psychological treatment, and immunosuppression protocols; and has a strong social support system that 
will help them to address the many challenges, including media exposure, body image adaptation, and societal reintegration..$^{110,25,66,85}$ Because face transplantation is not life-saving, it has been criticised for exposing otherwise healthy people to the risks of immunosuppression.

Fully informed consent is crucial for vascularised composite allotransplantation for the same reasons. Unlike an emergent, life-saving liver transplant, face transplantation should not be done without consent. Furthermore, the question has been raised as to whether consent can be truly informed if the recipient does not live with the defect for some time after an initial, salvage operation. ${ }^{86}$ In breast reconstruction, a waiting period can allow steadystate resolution of acute emotional and medical issues, giving the patient the chance of remaining with an acceptable conventional reconstruction, and even increase satisfaction with the eventual results of transplantation..$^{87,88}$ These effects might also be true for face transplantation. Severity of disfigurement does not predict psychological outcome and it is not always necessary to pursue an ideal aesthetic outcome to achieve the best possible psychological adjustment. One face transplantation has occurred in which multiple failed salvage attempts and a large exposed defect threatened the patient's life, leading to urgent transplantation with the patient's stated consent. ${ }^{89}$ The outcomes from this case might help to clarify the ethical grounds of emergent face transplantation.

Other ethical concerns about the recipient's age and the high costs of face transplantation continue to be debated..$^{10}$ The ethical dilemma of paediatric face transplantation involves informed consent, psychological instability during developmental years, lifetime risk of cancer, and complications of lifelong immunosuppression. The high financial cost of this procedureestimated at US\$300000-together with the cost of lifelong immunosuppressive treatment, precludes its widespread application. ${ }^{10}$ Thus, government or insurance funding is essential to the feasibility of face transplantation. This logistical concern became a stark reality in China, where almost all early recipients of hand transplants lost their allografts after authorities stopped supporting immunosuppressive treatment that most patients were unable to afford..$^{90}$

The resolution of many of these ethical dilemmas rests on the minimisation or elimination of conventional immunosuppression. Transplant tolerance is the ultimate ambition of solid organ transplantation and vascularised composite allotransplantation laboratories worldwide, but might not be realised in the near future. Until then, appropriate patient selection by a thorough screening process by a multidisciplinary team with standard immunosuppression treatment serves as the best safeguard against ethical challenges.

\section{Conclusion}

In the past 9 years, face transplantation has emerged as a viable and successful option to restore the appearance and function of patients with severe, devastating facial injuries. Depletional induction therapy and a standard three-drug immunosuppression regimen has enabled successful graft survival with highly encouraging functional and immunological outcomes. Tacrolimus has been a cornerstone of nearly all immunosuppression protocols with target trough levels of $10-15 \mathrm{ng} / \mathrm{mL}$ for the first 1-5 months with most patients subsequently lowering to a maintenance dose of $8-10 \mathrm{ng} / \mathrm{mL}$. Steroids have been safely tapered after a few months, with complete withdrawal possible within a year in some cases, depending on the immunosuppression regimen. Although acute rejection episodes commonly occur within the first year, all episodes have been controlled with pulse dose corticosteroids, and no cases of chronic rejection or graft-versus-host disease have been reported. The absence of chronic rejection in face transplant recipients might be a result of the prompt treatment of even the most mild acute rejection episodes and the lack of long-term follow-up data. Nevertheless, chronic rejection is possible and thus patients are advised to strictly adhere to their immunosuppression regimen and avoid mechanical trauma and environmental injury to decrease the risk of chronic graft deterioration.

The most important decision determining the success of facial transplantation remains patient selection. Rigorous preoperative psychiatric and psychological selection of patients deemed to be stable, motivated, and compliant by a multidisciplinary team is a crucial determinant of a safe and rapid recovery. The surgical approach and an early, aggressive rehabilitation programme might also dictate the rate of recovery to some extent. Facial sensation can be restored without direct trigeminal neurorrhaphy, although direct neurorrhaphy can accelerate sensory restoration. Conversely, restoration of motor function is critically dependent on facial nerve coaptation and generally takes longer than sensory reinnervation (6-8 months for motor recovery vs a few weeks for sensory recovery). A general guiding principle is that facial nerve coaptation should be done as close as possible to target muscles to optimise outcomes and minimise unpredictable reinnervation and synkinesis. Yet irrespective of surgical approach, all patients have regained both motor and sensory function and a high level of independence with significant improvements in quality of life.

Postoperative revisions have also been described, and such revisions seem not to cause major complications. The occlusion of the mandible and maxilla has a substantial effect on functional outcomes and therefore attempts should be made to optimise occlusion either by revisionary procedures (eg, tooth contouring or mid-facial osteotomy) or co-transplantation of tooth-bearing segments of maxilla and mandible whenever possible. Concurrent upper extremity transplantation continues to present challenges, which warrants further discussion as to whether combined hand and face transplantation should be a staged procedure 
or avoided altogether. Similarly, serological mismatches often lead to infectious or oncological complications and should be avoided (eg, Epstein-Barr virus) or pre-emptively treated (eg, cytomegalovirus).

At present, research goals are to minimise immunosuppression, and to refine functional and aesthetic outcomes by optimising neurological recovery, craniofacial alignment, and revision. Other future aims include the standardisation of clinical protocols and outcome measures, a multidisciplinary effort to move towards a standard-of-care approach, and coverage by health insurance. Further collaboration and sharing of methods and outcomes is needed to achieve such advances in this small but rapidly expanding specialty.

\section{Contributors}

SK, PSB, RM, and EDR planned the Review, searched for and assessed the published work, wrote the first draft, and revised the Review. CS and RNB planned the Review, assessed the published work, and revised the Review. GB assessed the published work and revised the Review.

\section{Declaration of interests}

We declare that we have no competing interests.

Acknowledgments

SK acknowledges partial support by The Paul and Daisy Soros Fellowship.

References

1 Losee JE, Fletcher DR, Gorantla VS. Human facial allotransplantation: patient selection and pertinent considerations. J Craniofac Surg 2012; 23: 260-64.

2 Bonanno A, Esmaeli B, Fingeret MC, Nelson DV, Weber RS. Social challenges of cancer patients with orbitofacial disfigurement. Ophthal Plast Reconstr Surg 2010; 26: 18-22.

3 Gamba A, Romano M, Grosso IM, et al. Psychosocial adjustment of patients surgically treated for head and neck cancer. Head Neck 1992; 14: 218-23.

4 Tartaglia A, McMahon BT, West SL, Belongia L. Workplace discrimination and disfigurement: the national EEOC ADA research project. Work 2005; 25: 57-65.

5 van der Wouden IC, Greaves-Otte JG, Greaves J, Kruyt PM, van Leeuwen O, van der Does E. Occupational reintegration of long-term cancer survivors. J Occup Med 1992; 34: 1084-89.

6 Rumsey N, Harcourt D. The psychology of appearance. Buckingham: Open University Press; 2005.

7 Rumsey N, Harcourt D. The Oxford handbook of the psychology of appearance. Oxford: Oxford University Press, 2012.

8 Pomahac B, Bueno EM, Sisk GC, Pribaz JJ. Current principles of facial allotransplantation: the Brigham and Women's Hospital experience. Plast Reconstr Surg 2013; 131: 1069-76.

9 Shanmugarajah K, Hettiaratchy S, Butler PE. Facial transplantation. Curr Opin Otolaryngol Head Neck Surg 2012; 20: 291-97.

10 Siemionow M, Ozturk C. Face transplantation: outcomes, concerns, controversies, and future directions. J Craniofac Surg 2012; 23: 254-59.

11 Gillies HMD. The principles and art of plastic surgery. Boston: Little, Brown, and Company, 1957.

12 Barret JP, Gavaldà J, Bueno J, et al. Full face transplant: the first case report. Ann Surg 2011; 254: 252-56.

13 Barret JP, Serracanta J, Collado JM, et al. Full face transplantation organization, development, and results-the Barcelona experience: a case report. Transplant Proc 2011; 43: 3533-34.

14 Barth R, Brazio P, Klassen D, et al. Immunologic outcomes in clinical face transplantation with large volume vascularized bone marrow component. Am J Transplant 2013; 13: 203.

15 BenMarzouk-Hidalgo OJ, Cordero E, Gómez-Cía T, et al. First face composite-tissue transplant recipient successfully treated for cytomegalovirus infection with preemptive valganciclovir treatment. Antimicrob Agents Chemother 2011; 55: 5949-51.

16 Carty MJ, Hivelin M, Dumontier C, et al. Lessons learned from simultaneous face and bilateral hand allotransplantation. Plast Reconstr Surg 2013; 132: 423-32.
17 Devauchelle B, Badet L, Lengelé B, et al. First human face allograft: early report. Lancet 2006; 368: 203-09.

18 Dorafshar AH, Bojovic B, Christy MR, et al. Total face, double jaw, and tongue transplantation: an evolutionary concept. Plast Reconstr Surg 2013; 131: 241-51.

19 Dubernard JM, Lengelé B, Morelon E, et al. Outcomes 18 months after the first human partial face transplantation. N Engl J Med 2007; 357: 2451-60.

20 Gomez-Cia T, Sicilia-Castro D, Infante-Cossio P, et al. Second human facial allotransplantation to restore a severe defect following radical resection of bilateral massive plexiform neurofibromas. Plast Reconstr Surg 2011; 127: 995-96.

21 Gordon CR, Avery RK, Abouhassan W, Siemionow M. Cytomegalovirus and other infectious issues related to face transplantation: specific considerations, lessons learned, and future recommendations. Plast Reconstr Surg 2011; 127: 1515-23.

22 Gordon CR, Siemionow M, Papay F, et al. The world's experience with facial transplantation: what have we learned thus far? Ann Plast Surg 2009; 63: 572-78.

23 Guo S, Han Y, Zhang X, et al. Human facial allotransplantation: a 2-year follow-up study. Lancet 2008; 372: 631-38.

24 Infante-Cossio P, Barrera-Pulido F, Gomez-Cia T, et al. Facial transplantation: a concise update. Med Oral Patol Oral Cir Bucal 2013; 18: e263-71.

25 Lantieri L, Hivelin M, Audard V, et al. Feasibility, reproducibility, risks and benefits of face transplantation: a prospective study of outcomes. Am J Transplant 2011; 11: 367-78.

26 Lantieri L, Meningaud JP, Grimbert P, et al. Repair of the lower and middle parts of the face by composite tissue allotransplantation in a patient with massive plexiform neurofibroma: a 1-year follow-up study. Lancet 2008; 372: 639-45.

27 Morelon E, Dubois V, Testelin S, et al. Face transplantation with combined hematopoietic stem cell infusion and vascularized bone marrow transplantation is not associated with mixed chimerism in humans. Am J Transplant 2013; 13: 202-03.

28 Morelon E, Kanitakis J, Petruzzo P. Immunological issues in clinical composite tissue allotransplantation: where do we stand today? Transplantation 2012; 93: 855-59.

29 Morelon E, Testelin S, Petruzzo P, et al. Face transplantation with combined hematopoietic stem cell infusion and vascularized bone marrow: first year of follow-up. Transpl Int 2011; 24: 75.

30 Morris P, Bradley A, Doyal L, et al. Face transplantation: a review of the technical, immunological, psychological and clinical issues with recommendations for good practice. Transplantation 2007; 83: 109-28.

31 Petruzzo P, Dubernard JM. The International Registry on Hand and Composite Tissue allotransplantation. Clin Transpl 2011; 25: 247-53.

32 Petruzzo P, Kanitakis J, Badet L, et al. Long-term follow-up in composite tissue allotransplantation: in-depth study of five (hand and face) recipients. Am J Transplant 2011; 11: 808-16.

33 Petruzzo P, Testelin S, Kanitakis J, et al. First human face transplantation: 5 years outcomes. Transplantation 2012; 93: 236-40.

34 Pomahac B, Pribaz J, Eriksson E, et al. Restoration of facial form and function after severe disfigurement from burn injury by a composite facial allograft. Am J Transplant 2011; 11: 386-93.

35 Siemionow M, Ozturk C. An update on facial transplantation cases performed between 2005 and 2010. Plast Reconstr Surg 2011; 128: 707e-20e.

36 Siemionow M, Papay F, Alam D, et al. Near-total human face transplantation for a severely disfigured patient in the USA. Lancet 2009; 374: 203-09.

37 Siemionow MZ, Papay F, Djohan R, et al. First U.S. near-total human face transplantation: a paradigm shift for massive complex injuries. Plast Reconstr Surg 2010; 125: 111-22.

38 Torres JJ, Ferrer B, Barret JP, et al. First complete full-face allograft transplantation, clinicopathologic features of graft rejection. Mod Pathol 2012; 25: 135A-A.

39 Pomahac B, Pribaz J, Eriksson E, et al. Three patients with full facial transplantation. N Engl J Med 2012; 366: 715-22.

40 Diaz-Siso JR, Parker M, Bueno EM, et al. Facial allotransplantation: a 3-year follow-up report. J Plast Reconstr Aesthet Surg 2013; 66: 1458-63.

41 Shanmugarajah K, Hettiaratchy S, Clarke A, Butler PE. Clinical outcomes of facial transplantation: a review. Int J Surg 2011; 9: 600-07. 
42 Pomahac B. Facial transplantation-the Boston, Massachusetts clinical experience. State of the Art: Facial Reconstruction \& Transplantation; Baltimore, MD, USA; May 17-19, 2013

43 Kanitakis J. Transmission of rosacea from the graft in facial allotransplantation. Am J Transplant 2011; 11: 1338-39.

44 Kaufman CL, Ouseph R, Blair B, et al. Graft vasculopathy in clinical hand transplantation. Am J Transplant 2012; 12: 1004-16.

45 Mundinger GS, Nam AJ, Hui-Chou HG, et al. Nonhuman primate model of fibula vascularized composite tissue allotransplantation demonstrates donor-recipient bony union. Plast Reconstr Surg 2011; 128: 1193-204.

46 Cavadas P. Speed-update on world experience with clinical VCA ASRT 3rd Biennial Meeting; Chicago, IL, USA; Nov 15-17, 2012.

47 Chelmoński A, Jabłecki J, Szajerka T. Insidious course of cytomegalovirus infection in hand transplant recipient: case report, diagnostics, and treatment. Transplant Proc 2011; 43: 2827-30.

48 Fishman JA, Emery V, Freeman R, et al. Cytomegalovirus in transplantation - challenging the status quo. Clin Transplant 2007; 21: $149-58$.

49 Grossi P, Minoli L, Percivalle E, Irish W, Vigano M, Gerna G. Clinical and virological monitoring of human cytomegalovirus infection in 294 heart transplant recipients. Transplantation 1995; 59: 847-51.

50 Ho M. Advances in understanding cytomegalovirus infection after transplantation. Transplant Proc 1994; 26 (suppl 1): 7-11.

51 Cendales LC, Kanitakis J, Schneeberger S, et al. The Banff 2007 working classification of skin-containing composite tissue allograft pathology. Am J Transplant 2008; 8: 1396-400.

52 Unadkat JV, Schneeberger S, Horibe EH, et al. Composite tissue vasculopathy and degeneration following multiple episodes of acute rejection in reconstructive transplantation. Am J Transplant 2010; 10: $251-61$

53 Siemionow M, Gharb BB, Rampazzo A. Pathways of sensory recovery after face transplantation. Plast Reconstr Surg 2011; 127: 1875-89.

54 Connor NP, Abbs JH. Orofacial proprioception: analyses of cutaneous mechanoreceptor population properties using artificial neural networks. J Commun Disord 1998; 31: 535-42.

55 Nordin M, Hagbarth KE. Mechanoreceptive units in the human infra-orbital nerve. Acta Physiol Scand 1989; 135: 149-61.

56 Hwang K, Hwang JH, Cho HJ, Kim DJ, Chung IH. Horizontal branch of the supraorbital nerve and temporal branch of the facial nerve. J Craniofac Surg 2005; 16: 647-49.

57 Shankland WE 2nd. The trigeminal nerve. Part III: The maxillary division. Cranio 2001; 19: 78-83.

58 Siemionow M, Gharb BB, Rampazzo A. The face as a sensory organ. Plast Reconstr Surg 2011; 127: 652-62.

59 Canan S, Asim OM, Okan B, Ozek C, Alper M. Anatomic variations of the infraorbital foramen. Ann Plast Surg 1999; 43: 613-17

60 Aziz SR, Marchena JM, Puran A. Anatomic characteristics of the infraorbital foramen: a cadaver study. J Oral Maxillofac Surg 2000; 58: 992-96.

$61 \mathrm{Hu}$ KS, Kwak HH, Song WC, et al. Branching patterns of the infraorbital nerve and topography within the infraorbital space. J Craniofac Surg 2006; 17: 1111-15.

62 Hwang K, Nam YS, Choi HG, Han SH, Hwang SH. Cutaneous innervation of lower eyelid. J Craniofac Surg 2008; 19: 1675-77.

63 Singhal D, Pribaz JJ, Pomahac B. The Brigham and Women's Hospital face transplant program: a look back. Plast Reconstr Surg 2012; 129: 81e-88e.

64 Pomahac B, Pribaz J. Facial composite tissue allograft. J Craniofac Surg 2012; 23: 265-67.

65 Guntinas-Lichius O. Outcomes 18 months after the first human partial face transplantation. N Engl J Med 2008; 358: 2179-80.

66 Siemionow MZ, Gordon CR. Institutional review board-based recommendations for medical institutions pursuing protocol approval for facial transplantation. Plast Reconstr Surg 2010; 126: $1232-39$

67 Vargas CD, Aballéa A, Rodrigues EC, et al. Re-emergence of hand-muscle representations in human motor cortex after hand allograft. Proc Natl Acad Sci USA 2009; 106: 7197-202.

68 Schneeberger S, Landin L, Jableki J, et al, and the ESOT CTA Working Group. Achievements and challenges in composite tissue allotransplantation. Transpl Int 2011; 24: 760-69.
69 Faggin BM, Nguyen KT, Nicolelis MA. Immediate and simultaneous sensory reorganization at cortical and subcortical levels of the somatosensory system. Proc Natl Acad Sci USA 1997; 94: 9428-33.

70 Meningaud JP, Paraskevas A, Ingallina F, Bouhana E, Lantieri L. Face transplant graft procurement: a preclinical and clinical study. Plast Reconstr Surg 2008; 122: 1383-89.

71 Coffman KL, Gordon C, Siemionow M. Psychological outcomes with face transplantation: overview and case report. Curr Opin Organ Transplant 2010; 15: 236-40.

72 Jacobs JM, Dec W, Levine JP, et al. Best face forward: virtual modeling and custom device fabrication to optimize craniofacial vascularized composite allotransplantation. Plast Reconstr Surg 2013 131: 64-70.

73 Fisher M, Dorafshar A, Bojovic B, Manson PN, Rodriguez ED. The evolution of critical concepts in aesthetic craniofacial microsurgical reconstruction. Plast Reconstr Surg 2012; 130: 389-98.

74 Haddock NT, Saadeh PB, Siebert JW. Achieving aesthetic results in facial reconstructive microsurgery: planning and executing secondary refinements. Plast Reconstr Surg 2012; 130: 1236-45.

75 Gupta A, Jain GK, Raghubir R. A time course study for the development of an immunocompromised wound model, using hydrocortisone. J Pharmacol Toxicol Methods 1999; 41: 183-87.

76 Humar A, Ramcharan T, Denny R, Gillingham KJ, Payne WD, Matas AJ. Are wound complications after a kidney transplant more common with modern immunosuppression? Transplantation 2001; 72: 1920-23.

77 Littlewood KE. The immunocompromised adult patient and surgery. Best Pract Res Clin Anaesthesiol 2008; 22: 585-609.

78 Hautz T, Wolfram D, Grahammer J, et al. Mechanisms and mediators of inflammation: potential models for skin rejection and targeted therapy in vascularized composite allotransplantation. Clin Dev Immunol 2012; 2012: 757310.

79 Barret JP, Serracanta J. LeFort I osteotomy and secondary procedures in full-face transplant patients. J Plast Reconstr Aesthet Surg 2013; 66: 723-25.

80 Svenaeus F. Organ transplantation and personal identity: how does loss and change of organs affect the self? J Med Philos 2012; 37: 139-58.

81 Gordon CR, Susarla SM, Peacock ZS, Kaban LB, Yaremchuk MJ. Le Fort-based maxillofacial transplantation: current state of the ar and a refined technique using orthognathic applications. J Craniofac Surg 2012; 23: 81-87.

82 Gordon CR, Susarla SM, Peacock ZS, et al. Osteocutaneous maxillofacial allotransplantation: lessons learned from a novel cadaver study applying orthognathic principles and practice. Plast Reconstr Surg 2011; 128: 465e-79e.

83 Blondeel P. Facial transplantation-the Gent, Belgium clinical experience. State of the Art: Facial Reconstruction \& Transplantation; Baltimore, MD, USA; May 17-19, 2013.

84 Brown EN, Dorafshar AH, Bojovic B, et al. Total face, double jaw, and tongue transplant simulation: a cadaveric study using computer-assisted techniques. Plast Reconstr Surg 2012; 130: 815-23.

85 Errico M, Metcalfe NH, Platt A. History and ethics of hand transplants. JRSM Short Reports 2012; 3: 74

86 Breidenbach W, Lantieri L, Manson P, Menick F, Pomahac B Walton R. Interactive panel and complicated cases: what is the true role for facial transplantation? State of the Art: Facial Reconstruction \& Transplantation; Baltimore, MD, USA; May 17-19, 2013.

87 Guyomard V, Leinster S, Wilkinson M, Servant JM, Pereira J. A Franco-British patients' and partners' satisfaction audit of breast reconstruction. J Plast Reconstr Aesthet Surg 2009; 62: 782-89.

88 Haekens CM, Enajat M, Keymeulen K, Van der Hulst RR. Self-esteem and patients' satisfaction after deep inferior epigastric perforator flap breast reconstruction. Plast Surg Nurs 2011; 31: 160-66.

89 Press TA. Emergency face transplant successfully performed in Poland. 2013. http://www.cbsnews.com/8301-204_162-57585664/ emergency-face-transplant-successfully-performed-in-poland/ (accessed June 1, 2013)

90 Petruzzo P, Lanzetta M, Dubernard JM, et al. The International Registry on Hand and Composite Tissue Transplantation. Transplantation 2010; 90: 1590-94. 